\title{
Material Compatibility Evaluation for DWPF Nitric- Glycolic Acid - Literature Review
}

J. I. Mickalonis

T. E. Skidmore

June 2013

Savannah River National Laboratory Savannah River Nuclear Solutions, LLC Aiken, SC 29808

Prepared for the U.S. Department of Energy under contract number DE-AC09-08SR22470. 
SRNL-STI-2013-00281

Revision 0

\section{DISCLAIMER}

This work was prepared under an agreement with and funded by the U.S. Government. Neither the U.S. Government or its employees, nor any of its contractors, subcontractors or their employees, makes any express or implied:

1. warranty or assumes any legal liability for the accuracy, completeness, or for the use or results of such use of any information, product, or process disclosed; or

2. representation that such use or results of such use would not infringe privately owned rights; or

3. endorsement or recommendation of any specifically identified commercial product, process, or service.

Any views and opinions of authors expressed in this work do not necessarily state or reflect those of the United States Government, or its contractors, or subcontractors.

\section{Printed in the United States of America \\ Prepared for U.S. Department of Energy}


Keywords: DWPF, corrosion, metals, polymers

Retention: Permanent

\section{Material Compatibility Evaluation for DWPF Nitric- Glycolic Acid - Literature Review}

J. I. Mickalonis
T. E. Skidmore

June 2013

Savannah River National Laboratory Savannah River Nuclear Solutions, LLC Aiken, SC 29808

Prepared for the U.S. Department of Energy under contract number DE-AC09-08SR22470. 


\section{REVIEWS AND APPROVALS}

\section{AUTHOR:}

J. I. Mickalonis, Materials Science \& Technology Date

T. E. Skidmore, Materials Science \& Technology Date

TECHNICAL REVIEW:

\begin{tabular}{ll}
\hline K. J. Imrich, Materials Science \& Technology Date & D
\end{tabular}

APPROVAL:

K. E. Zeigler, Manager

Date

Materials Science \& Technology

D. R. Click, Manager

Date

Environmental \& Chemical Process Technology Research Programs

E. J. Freed, Manager

Date

SRR Engineering 


\section{ACKNOWLEDGEMENTS}

The authors wish to acknowledge the following individuals in the preparation of this document: Heather H. Burns, D. L. Lambert, M. E. Stone, and E. W. Holtzscheiter. 


\section{EXECUTIVE SUMMARY}

Glycolic acid is being evaluated as an alternative for formic and nitric acid in the DWPF flowsheet. Demonstration testing and modeling for this new flowsheet has shown that glycolic acid and glycolate has a potential to remain in certain streams generated during the production of the nuclear waste glass. A literature review was conducted to assess the impact of glycolic acid on the corrosion of the materials of construction for the DWPF facility as well as facilities downstream which may have residual glycolic acid and glycolates present. The literature data was limited to solutions containing principally glycolic acid. The reported corrosion rates and degradation characteristics have shown the following for the materials of construction.

- For C276 alloy, the primary material of construction for the CPC vessels, corrosion rates of either 2 or 20 mpy were reported up to a temperature of $93{ }^{\circ} \mathrm{C}$.

- For the austenitic stainless steels, 304L and 316L, variable rates were reported over a range of temperatures, varying from 2 mpy up to $200 \mathrm{mpy}$ (at $100^{\circ} \mathrm{C}$ ).

- For 690, G30, Allcorr, Ultimet and Stellite alloys no data were available.

- For relevant polymers where data are available, the data suggests that exposure to glycolic acid is not detrimental.

The literature data had limited application to the DWPF process since only the storage and feed vessels, pumps and piping used to handle the glycolic acid are directly covered by the available data. These components are either 304L or 316L alloys for which the literature data is inconsistent (See Bullet 2 above). Corrosion rates in pure glycolic acid solutions also are not representative of the DWPF process streams. This stream is complex and contains aggressive species, i.e. chlorides, sulfates, mercury, as well as antifoaming agents which cumulatively have an unknown effect on the corrosion rates of the materials of construction. Therefore, testing is recommended to investigate any synergistic effects of the aggressive species and to verify the performance of materials in the key process vessels as well as downstream vessels and processes such as the evaporator where heating is occurring. The following testing would provide data for establishing the viability of these components.

- Electrochemical testing - evaluate the corrosion rate and susceptibility to localized corrosion within the SRAT, SME, OGCT, Quencher and Evaporator. Testing would be conducted at operational temperatures in simulants with ranges of glycolic acid, iron, chloride, sulfate, mercury, and antifoaming agents.

- Hot-wall testing - evaluate the corrosion under heat transfer conditions to simulate those for heating coils and evaporator coil surfaces. Testing would be at nominal chemistries with concentration of glycolic acid, chloride, sulfate and mercury at high expected concentrations. Some tests would be performed with antifoaming agents. 
- Melter coupon testing - evaluate the performance of alloy 690 in melter feeds containing glycolic acid. This testing would be conducted as part of the melter flammability testing.

- Polymer testing - evaluate changes in polymer properties in immersion testing with DWPF simulants to provide product-specific data for service life evaluation and analyze the Hansen solubility parameters for relevant polymers in glycolic vs. formic acid.

During this literature review process, the difficulties associated with measuring the liquid level in formic acid tanks were revealed. A test is recommended to resolve this issue prior to the introduction of glycolic acid into the DWPF. This testing would evaluate the feasibility of using ultrasonic inspection techniques to determine liquid level and other desirable attributes of glycolic acid in DWPF storage tanks and related equipment. 


\section{TABLE OF CONTENTS}

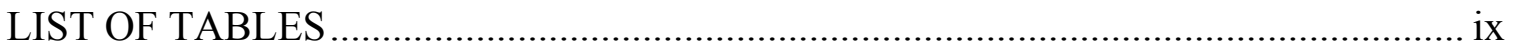

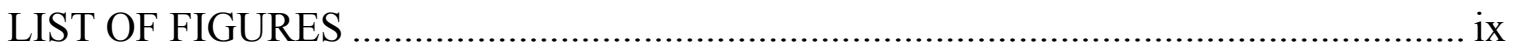

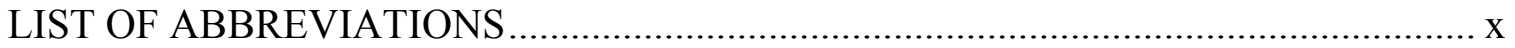

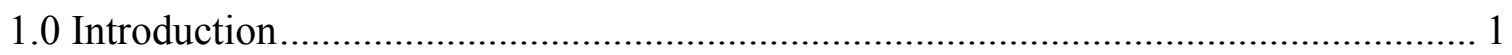

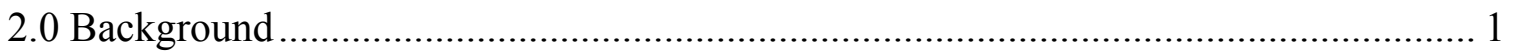

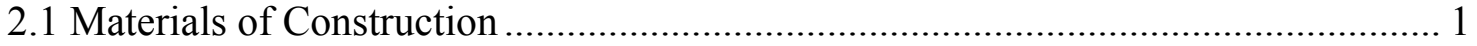

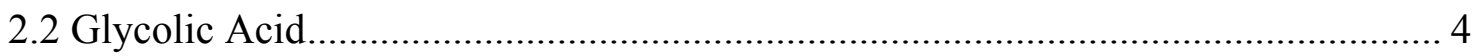

2.2 Previous Testing and Evaluations....................................................................... 4

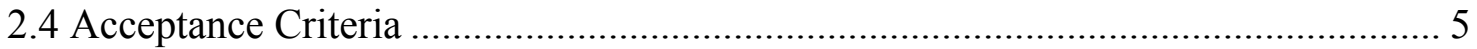

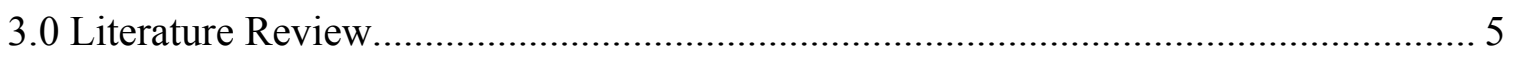

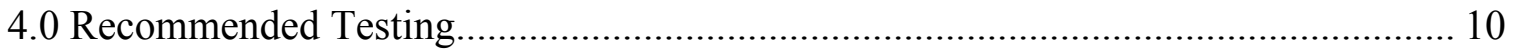

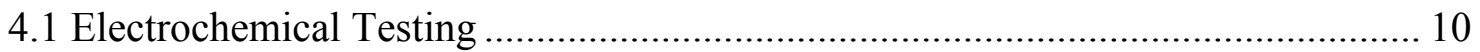

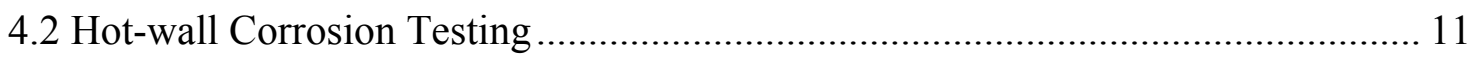

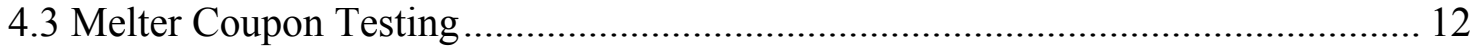

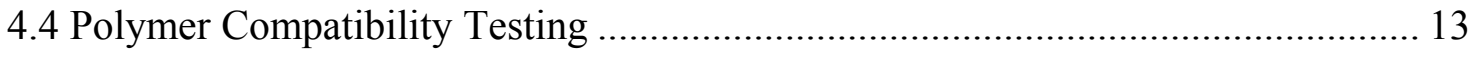

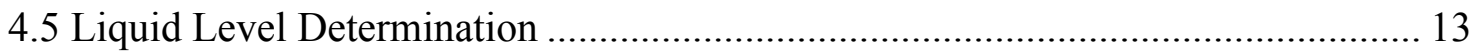

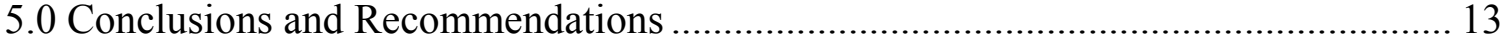

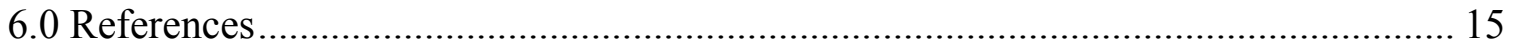

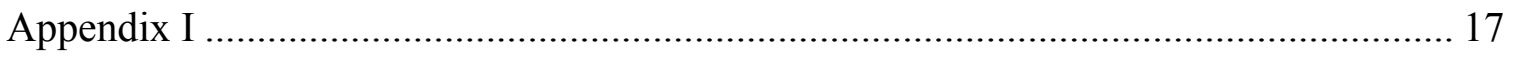

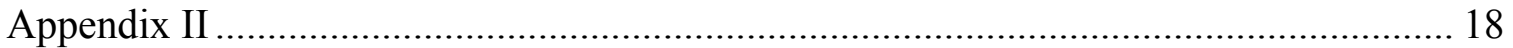




\section{LIST OF TABLES}

Table $1 \quad$ Materials of construction for the DWPF process and downstream facilities impacted by the presence of glycolic acid or glycolates.............................. 3

Table 2 Polymeric Material Resistance to 70\% Glycolic Acid .............................. 7

Table 3 Hansen Solubility Parameters for Glycolic and Formic Acid ..............................9

Table AI-1 Metallic materials of construction nominal compositions ........................ 17

Table AII-1 Summary of Components Evaluated for DWPF Structural Integrity Program.......................................................................................... 18

\section{LIST OF FIGURES}

Figure 1 DWPF process overview with key vessels identified ................................ 2

Figure 2 DWPF downstream facilities impacted by the waste recycle containing glycolic acid or glycolate ...................................................................... 2

Figure 3 Hot-wall testing apparatus for testing corrosion resistance of materials under heat transfer conditions ................................................................ 12

Figure $4 \quad$ Melter coupon analysis per ASTM G54 …………………………….... 12 


\section{LIST OF ABBREVIATIONS}

\begin{tabular}{ll} 
ABS & Acrylonitrile Butadiene Styrene \\
ARP & Actinide Removal Process \\
CPC & Chemical Process Cell \\
CPP & Cyclic Potentiodynamic Polarization \\
CPVC & Chlorinated polyvinyl chloride \\
DWPF & Defense Waste Processing Facility \\
EPDM & ethylene propylene diene monomer \\
ETFE & ethylene-tetrafluoroethylene copolymer \\
FEP & fluorinated ethylene propylene \\
HLW & High Level Waste \\
HSP & Hansen Solubility Parameter \\
LPPP & Low Point Pump Pit \\
LPR & Linear Polarization Resistance \\
MCU & Modular Caustic Unit \\
MFT & Melter Feed Tank \\
mpy & mils per year \\
MWWT & Mercury Wash Water Tank \\
NBR & Nitrile butadiene rubber \\
NDE & Non-destructive Examination \\
OCP & Open-circuit Potential \\
PGA & Polyglycolic Acid \\
PFA & Perfluoroalkoxy \\
PPT & Precipitate Pump Tank \\
PRFT & Precipitate Reactor Feed Tank \\
PEEK & Polyetherether ketone \\
PP & Polypropylene \\
PPS & Polyphenylene sulfide \\
PRFT & Precipitate Reactor Feed Tank \\
PVC & Polyvinyl vhloride \\
PVDF & Polyvinylidene fluoride \\
SEFT & Strip Effluent Feed Tank \\
SME & Slurry Mix Evaporator \\
SMECT & Slurry Mix Evaporator Condensate Tank \\
SRAT & Sludge Receipt Adjustment Tank \\
\hline PRA &
\end{tabular}




\subsection{Introduction}

The Defense Waste Processing Facility (DWPF) is evaluating an alternate reductant flowsheet using glycolic acid in place of formic acid to improve operational conditions, especially processing time and a reduction in producing flammable quantities of hydrogen. To implement this change in the facility, the current systems and components used to provide the $90 \mathrm{wt} . \%$ formic acid will be used to provide the $70 \mathrm{wt} \%$ glycolic acid to the facility. All the glycolic acid is not utilized during the feed processing and glycolic acid or glycolate remains in the system. DWPF requested a materials evaluation for the components of the DWPF facility and downstream facilities that would be exposed to glycolic acid or glycolate [1].

The materials evaluation consisted of compiling available literature data for the degradation of specified materials of construction to glycolic acid, glycolates or solutions containing these components [2]. The data was limited to solutions containing principally glycolic acid, so are not representative of DWPF processing solutions. Corrosion rates for metal and degradation characterizations for non-metals ranged from acceptable to unsatisfactory. In some cases the rates were higher than those previously noted within the DWPF structural integrity program [11]. Data was also not available for all alloys of interest. Therefore, data acquisition of pertinent data is recommended to support safe disciplined operations and the DWPF structural integrity program. A targeted experimental plan is provided for review.

\subsection{Background}

The materials of construction are discussed for the various components within the DWPF and for facilities downstream that may be affected by the presence of glycolic acid and glycolate. Additionally, basic property information of glycolic acid is presented that may have an impact on the materials of construction. The observations from previous work are highlighted that also might impact the materials of construction. A general overview of the DWPF structural integrity program is also given to identify the acceptance criteria for measured corrosion.

\subsection{Materials of Construction}

The use of glycolic acid as the alternate reductant for the DWPF process impacts numerous vessels within the DWPF but especially those vessels in the chemical processing cell (CPC). These vessels are highlighted in Figure 1. The heated or hot surfaces in these vessels will present the greatest challenges including the SRAT/SME condenser and the heating coils. Additionally, glycolate will contact systems and equipment in other facilities within the SRS waste cycle from the DWPF recycle waste that is sent back to the tank farm. The recycle waste is inhibited with caustic prior to transfer so glycolates are present in this waste.

The recycle waste is reduced through the high level waste evaporator, transported via the transfer lines, and in part, processed through the ARP and MCU before being sent back to the DWPF. The overheads from the HLW evaporators are not anticipated to contain glycolate [32], so the Effluent Treatment Facility is not expected to be impacted. The decontaminated salt solution which comes from the MCU and ARP processes will 
contain glycolates and be sent to Saltstone for combining with grout [ref]. The facilities impacted by the presence of glycolic acid and glycolate in the DWPF recycle stream are shown schematically in Figure 2.

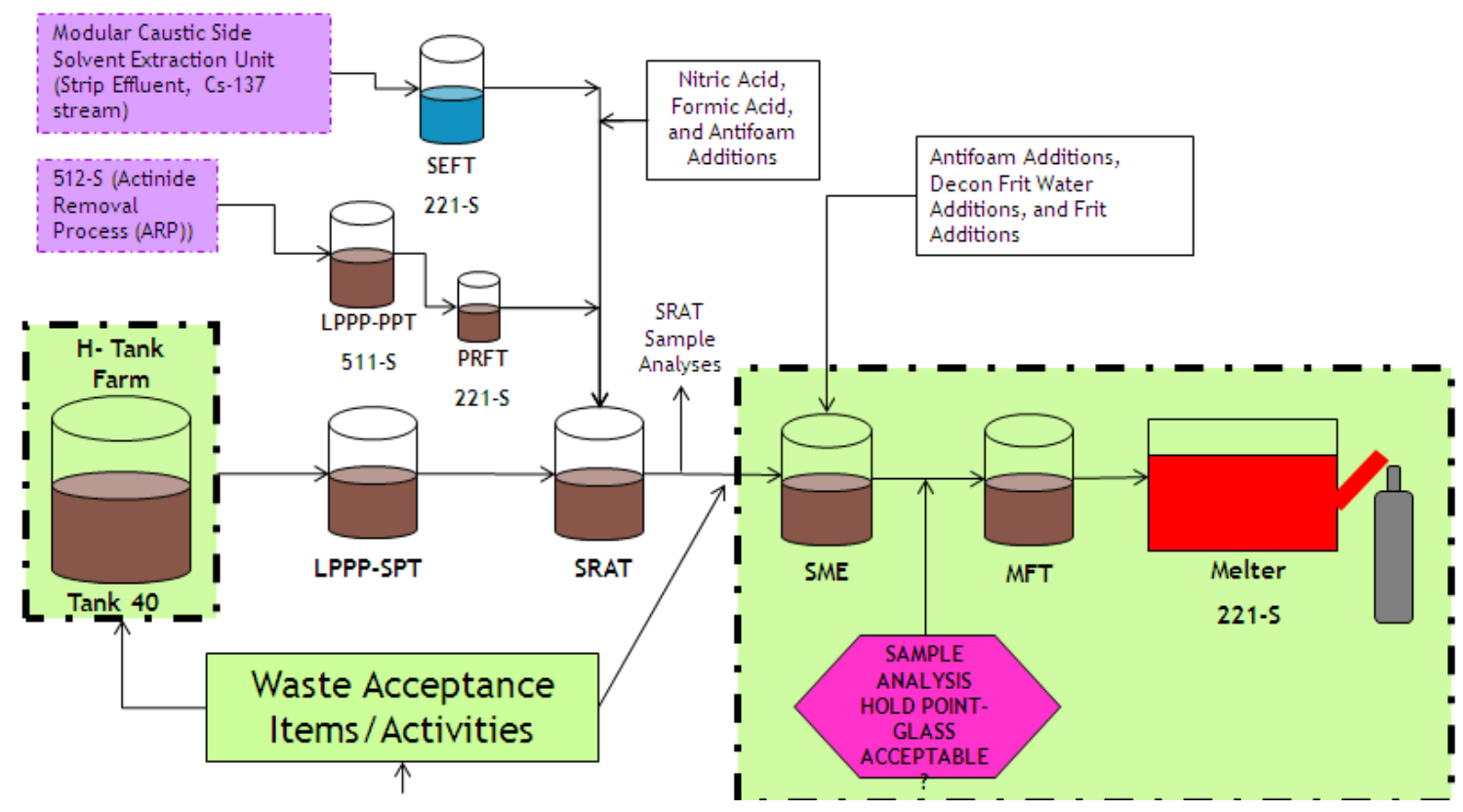

Figure 1 DWPF process overview with key vessels identified for current flowsheet

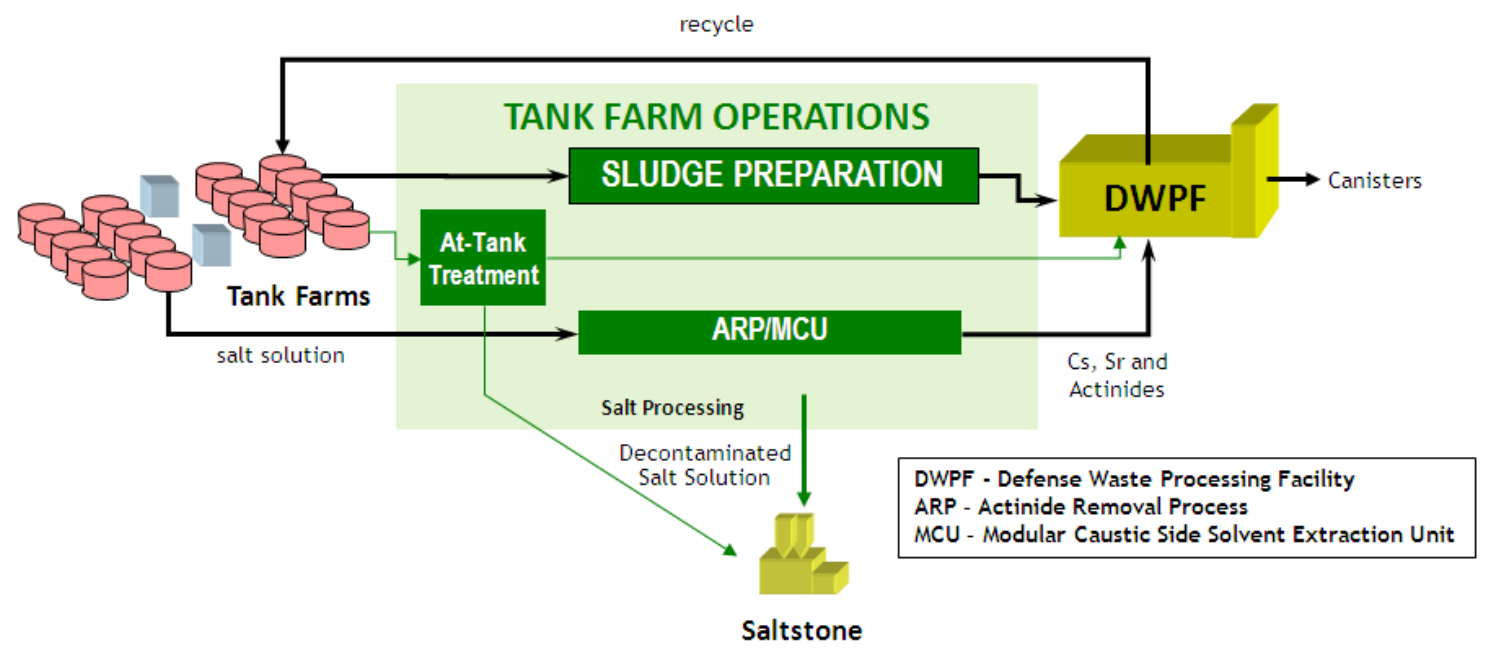

Figure 2 DWPF downstream facilities (including Tank 22 and the $2 \mathrm{H}$ Evaporator) impacted by the waste recycle containing glycolic acid or glycolate

The materials of construction, which is shown in Table 1, varies from high nickel alloys to carbon steel and also includes a range of polymers. Although polymers are generally not structural or permanent, long-life components, any failures associated with premature or unexpected degradation can impact the facilities, both in terms of productivity and personnel exposure if needed for repair or replacement. 
Table 1 Materials of construction for the DWPF process and downstream facilities impacted by the presence of glycolic acid or glycolates

\begin{tabular}{|c|c|}
\hline Material of Construction & Locations \\
\hline $\mathrm{C}-276$ & $\begin{array}{l}\text { SEFT Vessel, Coils and agitator } \\
\text { Transfer and rack jumpers } \\
\text { SRAT Vessel, Condenser, Coils } \\
\text { SME Vessel, Condenser, Coils } \\
\text { SME Condensate Tank } \\
\text { Melter Feed Tank, Coils } \\
\text { Off-gas condenser and condensate tank } \\
\text { Melter off-gas line isolation valve } \\
\text { Backup off-gas quencher }\end{array}$ \\
\hline $304 \mathrm{~L}$ & $\begin{array}{l}\text { Inner transfer lines from MCU } \\
\text { Transfer jumpers } \\
\text { Dilution and feed tank for glycolic acid } \\
\text { (formerly used for formic acid) } \\
2 \mathrm{H} \text { evaporator pot, condenser, piping, } \\
\text { collection tanks, valves and pumps }\end{array}$ \\
\hline $316 \mathrm{~L}$ & $\begin{array}{l}\text { Storage tank and feed tank and piping } \\
\text { associated with glycolic acid (formerly } \\
\text { used for formic acid) } \\
\text { SMECT } \\
\text { MWWT } \\
\text { 2H Evaporator valves and pumps } \\
\text { DWPF valves } \\
\text { Saltstone paddles and mixer housing }\end{array}$ \\
\hline G30 & HLW 2H Evaporator tube bundle \\
\hline Carbon steel (A53) & Outer transfer lines \\
\hline Stellite 6B (castings and overlay) & $\begin{array}{l}\text { SME and MFT pumps, coil supports, and } \\
\text { guides, Saltstone augurs }\end{array}$ \\
\hline Ultimet ${ }^{\circledR}$ & $\begin{array}{l}\text { Agitator blades, SME coil clam shells and } \\
\text { elbow on coil downcomer }\end{array}$ \\
\hline Teldyne Allvac® Allcor & Off-gas quencher \\
\hline Inconel $\AA 690$ & $\begin{array}{l}\text { Melter top head component and primary } \\
\text { off-gas line }\end{array}$ \\
\hline UHMWPE & Sleeve packing \\
\hline Teflon impregnated asbestos & Jumper gaskets \\
\hline Viton $\AA A$ & DWPF and $2 \mathrm{H}$ evaporator pumps \\
\hline Grafoil@ gaskets & DWPF and MCU pumps \\
\hline Teflon & $2 \mathrm{H}$ evaporator pumps \\
\hline Tefzel® & $2 \mathrm{H}$ evaporator and MCU pumps \\
\hline EPDM & $2 \mathrm{H}$ evaporator pumps \\
\hline Isolast $\AA$ & $\mathrm{MCU}$ \\
\hline Carbon filled PEEK & $\mathrm{MCU}$ \\
\hline CPVC & MCU \\
\hline
\end{tabular}


The nominal compositions of the metallic materials of construction are given in Appendix I.

\subsection{Glycolic Acid}

Glycolic acid $(\mathrm{HOCH} 2 \mathrm{COOH})$ is an alpha-hydroxy carboxylic acid with dual chemical functionality (acid and alcohol groups). Although occurring naturally, glycolic acid is usually manufactured synthetically [3]. Glycolic acid is very soluble in water and numerous other alcohols and solvents. Glycolic acid has a unique combination of properties that makes it valuable especially when descaling, as noted in SRNL testing [4] and is used as a component in cleaning formulations. The descaling capability results from the complex formation with glycolic acid and multivalent metal salts. An extensive literature review has been performed previously on this complex formation [9]. The hydroxyl and carboxylic functional groups of glycolic acid form five-member ring complexes with polyvalent metals. Other important features include low corrosiveness, non-flammability, high water solubility, negligible volatile organics, and ease of handling in liquid form. The low corrosiveness has been associated with the negligible chloride content [3]. Where corrosion is an issue, a mixture of $2 \%$ glycolic acid and $1 \%$ formic acid has been found to be very effective. The low chloride content of glycolic acid minimizes the potential for chloride stress corrosion damage. The glycolic/formic acid mixture is effective for removal of scale deposits without organic iron precipitation (i.e. iron is complexed).

An SRNL study on the physical properties of glycolic acid, its impurities, and radiation effects showed that the principle impurity with glycolic acid was sulfate [5]. Although the study evaluated the impact of an acid addition of $90 \%$ glycolic acid/10\% formic acid, the sulfate concentrations in the resultant feed were approximately $0.03 \mathrm{wt} \%$. Previous studies have shown that for changes in sulfate concentrations from 0.11 to $0.58 \mathrm{M}$ the general corrosion rate was not affected significantly for C276, Allcorr, I690 and Ultimet, but that C276 and I690 were susceptible to pitting [6]. Localized corrosion mechanisms, such as pitting, are generally the cause of premature failure of components.

\subsection{Previous Testing and Evaluations}

SRNL has conducted process testing to support the change in the alternate reductant from formic acid to glycolic acid [4, 7], evaluated the impact on some downstream facilities' processes [8, 9, 32], as well as modeled the melter off gas stream for destruction of glycolic acid [10]. From these investigations the following points were highlighted for further evaluation:

- Glycolate carryover (approximately $100 \mathrm{ppm}$ ) has been observed in the Slurry Mix Evaporator Condensate Tank (SMECT) during small scale Chemical Processing Cell (CPC) testing [4].

- A significant amount of glycolate carryover was predicted from offgas modeling of a small-scale melter demonstration of the glycolic-formic-nitric flowsheet, but no experimental data exists to confirm this result. Any glycolate that is entrained or evaporated from the melter would accumulate in the melter Off Gas Condensate Tank (OGCT). 
- Sodium glycolate would most likely result from the neutralization of glycolic acid with sodium hydroxide in the Recycle Collection Tank which would be sent to the $2 \mathrm{H}$ evaporator [32].

In the previous testing by Lambert et al, the vessel and internal components had reduced build up indicating a cleaning action of the glycolic acid. [4]. This result demonstrates that the glycolic-nitric flowsheet might keep the DWPF processing vessels cleaner than the current flowsheet, but the mechanism of this cleaning process may be a concern for metallic components. The glycolic acid may be complexing the sludge constituents that would deposit on these surfaces but the acid may also be reacting with the surface oxide and removing metal ions from the surface, i.e. corrosion. The mechanism(s) involved and the degree of corrosion that might occur needs to be further understood.

Another factor that needs to be considered is the effect of the antifoaming agent. The increasing use of antifoaming agent with the introduction of the ARP product adds another unknown for assessing the impact on corrosion along with the introduction of glycolic acid as the reductant. Previous studies by SRNL have shown that the antifoaming agent decomposes principally to long chain siloxanes and that the byproducts stay principally in the melter feed although species are also found in the SRAT condensate as well as in the MWWT [22]. Siloxanes as thin films have been noted to provide some protection to metallic surfaces [23-25]. Siloxane appears to act as a film forming inhibitor. For similar inhibitors such as silicates, if coverage is not adequate corrosion may increase [26].

\subsection{Acceptance Criteria}

The DWPF Structural Integrity Program has evaluated safety class and safety significant components for acceptable levels of degradation [11]. The evaluation included an assessment of operable material degradation mechanisms, structural design and inspection/test requirements. The evaluated data was taken from laboratory testing in simulated DWPF chemistries, pilot plant system coupon tests and inspection data from DWPF and pilot scale systems. In Appendix II, a summary table from Reference 11 is given which identifies the material of construction and the corrosion for a formic/nitric flowsheet. These values demonstrated that the corrosion rates were nominally all excellent with rates less than 2 mils per year (mpy). These rates do not take into consideration erosion that has been noted in the presence of the frit. The rate of 2 mpy was used as an acceptance criterion for comparison with the corrosion rates in the literature.

\subsection{Literature Review}

Glycolic acid is commonly a component in commercial cleaners including those used for cleaning and descaling stainless steel. Glycolic acid along with citric acid and formic acid were noted for the low corrosion rates experienced by stainless steels as well as their solubility for ferrous species [3]. The available literature data was limited to sources of compiled corrosion resistance information for different solutions and chemicals. The corrosion rates in pure glycolic acid ranged from excellent $(<2$ mpy) to unacceptable ( $>$ 
50 mpy) for most of the metallic materials of construction given in Table 1. However, corrosion data was not available for all materials (i.e. Ultimet, Stellite) [3, 12-17].

For alloy C276, slightly different estimates of the corrosion rates were given. The SRAT/SME heating coils will see the highest concentration of glycolic acid at elevated temperatures (coil surface temperature of $160^{\circ} \mathrm{C}\left(320^{\circ} \mathrm{F}\right)$. One source noted a rate of less than 2 mpy up to a temperature of $300^{\circ} \mathrm{F}\left(149^{\circ} \mathrm{C}\right)$ [12], while two other sources gave a rate of less than 20 mpy up to a temperature of $200^{\circ} \mathrm{F}\left(93^{\circ} \mathrm{C}\right)[13,14]$.

The operation window for 304L or 316L alloys is more restrictive and differed slightly with the source. A chemical resistance guide by Burkert Fluid Control Systems, which used a qualitative rating, showed some attack for stainless steels $(316,316 \mathrm{~L}, 303$, and 430) with limited suitability although conditions were not specified [16]. The limited suitability may be associated with ferritic stainless steels (430) since DuPont data showed corrosion rates on the order of 5-6 inches per year for 70\% glycolic acid at a temperature of $100^{\circ} \mathrm{C}\left(212^{\circ} \mathrm{F}\right)$ [17]. Under similar conditions, the corrosion rates of $304 \mathrm{~L}$ and $316 \mathrm{~L}$ were 214 and $80 \mathrm{mpy}$, respectively [17]. This corrosion rate dropped to less than $1 \mathrm{mpy}$ if $500 \mathrm{ppm} \mathrm{Fe}$ were added or if the test conditions were at $5 \%$ glycolic acid and $71{ }^{\circ} \mathrm{C}$ $\left(160^{\circ} \mathrm{F}\right)$. The test time was not given for these tests, but extended exposure may produce sufficient ferrous ions in solution to complex the glycolic acid and reduce the corrosion rate. The rates at elevated temperature without ferrous complex formation would be unacceptable while in the presence of ferrous ions would be excellent.

DuPont gave specific material recommendations for storage equipment of its $70 \%$ glycolic acid [3]. 304 stainless steel was recommended for temperatures up to $50{ }^{\circ} \mathrm{C}$ $\left(122^{\circ} \mathrm{F}\right)$, while 316 stainless steel was recommended for temperatures up to $70^{\circ} \mathrm{C}\left(158^{\circ}\right.$ F). Similar recommendations were given for piping. At elevated temperatures (above $70^{\circ} \mathrm{C}\left(158^{\circ} \mathrm{F}\right)$ ), particularly in the presence of mineral acids and water, DuPont specified materials of construction like silver linings. The recommendation for pumps differed and depended on the process conditions. In mild service, stainless steel was acceptable, while for harsh service, Hastelloy ${ }^{\circledR}$ (no specific alloy was listed), Alloy 20, AL-6XN, or titanium were recommended to be evaluated. Delineation between mild and harsh conditions was not given.

Two other sources gave slightly different rates. Reference 13 for 304 stainless steel listed the corrosion rate without specific concentrations as less than 2 mpy for temperatures up to $255^{\circ} \mathrm{F}\left(124{ }^{\circ} \mathrm{C}\right)$ and less than 20 mpy for temperatures up to $284{ }^{\circ} \mathrm{F}\left(140{ }^{\circ} \mathrm{C}\right)$. Additionally, 304L was not recommended for boiling conditions with a $10 \%$ concentration listed specifically. Reference 15 listed the corrosion rate as less than 20 mpy for temperatures up to $200{ }^{\circ} \mathrm{F}$ and $360{ }^{\circ} \mathrm{F}\left(93\right.$ and $182{ }^{\circ} \mathrm{C}$ ) for $304 / 304 \mathrm{~L}$ and 316/316L stainless steels, respectively.

DuPont, a manufacturer of glycolic acid, listed Monel and Inconel as suitable materials of construction. Data supplied by DuPont showed a maximum corrosion rate of 190 mpy for $70 \%$ glycolic acid at a temperature of $100^{\circ} \mathrm{C}\left(212^{\circ} \mathrm{F}\right)$ [17] for Inconel although the specific alloy was not given. The corrosion rates decreased with temperature or acid 
concentrations to values considered good ( $<20$ mpy) to excellent $(<2$ mpy). Similar relationships were also found for Monel (Ni-Cu alloys) and nickel.

The effect of glycolic acid on polymeric materials was more limited and qualitative. For polymers including nitrile rubber, EPDM, Viton ${ }^{\circledR}$, Kalrez ${ }^{\circledR}$, neoprene, PVC, PP, PVDF, PPS, and PEEK, the material was not affected by $70 \%$ glycolic acid. Only polyimide (Kapton ${ }^{\circledR}$, Vespel ${ }^{\circledR}$, are common trade names) was listed as unsuitable [16]. These qualitative classifications were based on industrial experience and limited laboratory data.

Data supplied by DuPont showed a wide variety of polymers which experienced no attack with limited swelling $(<10 \%)$ and strength loss $(<15 \%)$ [17]. Only two polymers, neoprene and Buna $\mathrm{N}$, were not recommended. Table 2 shows the data provided by DuPont [17].

Table 2 Polymeric Material Resistance to 70\% Glycolic Acid [17]*

\begin{tabular}{|c|c|c|c|}
\hline Material & Resistance & Material & Resistance \\
\hline 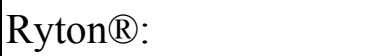 & A to $95^{\circ} \mathrm{C}$ & Tefzel® ETFE: & A to $125^{\circ} \mathrm{C}$ \\
\hline Penton $\AA$ : & $\begin{array}{l}\text { A to } 30^{\circ} \mathrm{C} \\
\mathrm{B} \text { to } 120^{\circ} \mathrm{C}\end{array}$ & $\begin{array}{l}\text { Teflon } \AA \text { FEP or } \\
\text { PFA: }\end{array}$ & A to $95^{\circ} \mathrm{C}$ \\
\hline Kynar®: & $\begin{array}{l}\text { A to } 20^{\circ} \mathrm{C} ; \\
\mathrm{B} \text { to } 50^{\circ} \mathrm{C} ; \\
\mathrm{C} \text { to } 65^{\circ} \mathrm{C} ; \\
\mathrm{NR} \text { to } 100^{\circ} \mathrm{C}\end{array}$ & Vinyl Ester: & $\begin{array}{l}(10 \%) \mathrm{A} / \mathrm{B} \text { to } 95^{\circ} \mathrm{C} ; \\
(70 \%) \mathrm{A} / \mathrm{B} \text { to } 40^{\circ} \mathrm{C}\end{array}$ \\
\hline Teflon $®$ TFE: & A to $100^{\circ} \mathrm{C}$ & KEL-F: & A to $40^{\circ} \mathrm{C}$ \\
\hline Polysulphone: & NI & Polypropylene: & A to $110^{\circ} \mathrm{C}$ \\
\hline Noryl $\AA$ : & $\mathrm{NI}$ & PVC: & A to $65^{\circ} \mathrm{C}$ \\
\hline ABS: & Strength loss at $30^{\circ} \mathrm{C}$. & Epoxy: & A to $20^{\circ} \mathrm{C}$ \\
\hline $\begin{array}{l}\text { Soft/Hard Natural } \\
\text { Rubber: }\end{array}$ & A to $50^{\circ} \mathrm{C}$ & $\begin{array}{l}\text { Impregnated Carbon } \\
\text { Graphite: }\end{array}$ & A to $250^{\circ} \mathrm{C}$ \\
\hline Halar® CTFE: & A to $40^{\circ} \mathrm{C}$ & Buna N (NBR): & NR \\
\hline Polyester Isophthalic: & $\mathrm{AC}$ to $75^{\circ} \mathrm{C}$ & Glass: & A to $100^{\circ} \mathrm{C}$ \\
\hline Polyethylene: & A to $65^{\circ} \mathrm{C}$ & Polyamide-imide: & $\mathrm{NI}$ \\
\hline CPVC: & A to $85^{\circ} \mathrm{C}$ & Acetal: & $\mathrm{NI}$ \\
\hline Polycarbonate: & $\mathrm{NI}$ & Acrylic: & $\mathrm{NI}$ \\
\hline Butyl: & $(10 \%) \mathrm{A}$ to $40^{\circ} \mathrm{C}$ & Furan: & $\mathrm{NI}$ \\
\hline Neoprene: & NR & Viton $\AA$ : & A \\
\hline
\end{tabular}

*A - no attack ( $<10 \%$ swelling, $<15 \%$ strength loss), B - minor attack $(<15 \%$ swelling, $<30 \%$ strength loss), $\mathrm{C}-$ moderate attack ( $>29 \%$ swelling, $<50 \%$ strength loss), NR - dissolves over time ( $>20 \%$ swelling, $>50 \%$ strength loss), NI - no information 
Specific polymer recommendations made by DuPont for processing equipment with glycolic acid were fiber-filled gaskets because they are less susceptible to failure [17]. This better performance may be attributed to the fiber reinforcement. The reinforcement aids in creep relaxation and also reduces the amount of polymer (elastomer in the case of compressed non-asbestos gaskets) present that may be susceptible to degradation. The DuPont data suggest that Kalrez ${ }^{\circledR}$ (perfluoroelastomer type), Viton ${ }^{\circledR}$ (fluoroelastomer type), and Nordel ${ }^{\circledR}$ EPDM elastomers are acceptable for O-rings with Kalrez ${ }^{\circledR}$ offering the highest level of performance. Limited experience shows that fiber reinforced plastic tanks are suitable for concentrations below $30 \%$ or for use in a heated storage building.

In general, the fluoropolymers such as Teflon ${ }^{\circledR}$ PTFE and Tefzel ${ }^{\circledR}$ ETFE copolymer offer the widest chemical resistance along with fluoroelastomers such as Viton ${ }^{\circledR}$ and perfluoroelastomers such as Kalrez ${ }^{\circledR}$. Therefore, the fluoropolymers used in the affected facilities are likely at the least risk for significant effects, though Kynar ${ }^{\circledR}$ PVDF is noted to have significant effects especially at $65^{\circ} \mathrm{C}\left(149^{\circ} \mathrm{F}\right)$ [17]. PVDF is less fluorinated than most other fluoropolymers so it does have some chemical sensitivity that the others do not share, such as limited resistance to strong bases, especially at elevated temperature, resulting in environmental stress-cracking. However, PVDF is not listed in Table 1 and is not known to be used in SRS facilities where exposure to strong base solutions is anticipated.

Data from Reference [29] for glycolic acid (no concentration specified) indicated that most plastics have good to excellent resistance with some exceptions. Caution is suggested when using ratings data from different references. These references may have variations in the basis for the rating and solutions of different concentrations. The ratings may be also for generic materials, not specific grades or formulations. Some of the more affected polymers noted in this reference include ABS (acrylonitrile butadiene styrene) copolymer and polyphenylene oxide (Noryl ${ }^{\circledR}$ PPO, rated C at $70{ }^{\circ} \mathrm{F},<20 \%$ swelling, $<50 \%$ loss of tensile strength, moderate attack).

Data from Reference [30] for glycolic acid (no concentration specified) suggested that most elastomers are also reasonably resistant, with notable exceptions of TFE/P (tetrafluoroethylene-propylene) copolymer (not recommended at $70{ }^{\circ} \mathrm{F}$ ), silicones (rated $\mathrm{C}$ at $70{ }^{\circ} \mathrm{F}$ for dynamic applications, $\mathrm{AB}$ to $70^{\circ} \mathrm{F}$ ), NBR (nitrile, $\mathrm{BC}$ rated at $70^{\circ} \mathrm{F}$, not recommended above $70^{\circ} \mathrm{F}$ ), polyacrylate (not recommended at $70^{\circ} \mathrm{F}$ ), polyurethane (not recommended at $70^{\circ} \mathrm{F}$ ), and natural rubber (not recommended at $10 \%$ at $70{ }^{\circ} \mathrm{F}$ ). These polymers also have similar ratings in formic acid, though formic acid concentrations of $88-100 \%$ are noted to affect several elastomer types which are not affected by glycolic acid or no data on glycolic acid were available. Also, formic acid was noted to affect Viton ${ }^{\circledR}$ elastomers to a significant extent, depending on concentration and temperature (not recommended for $60-100 \%$ at $70{ }^{\circ} \mathrm{F}$ ).

With limited or no data for at least some polymers, one way to assess the relative potential for degradation is the use of solubility parameters. This is particularly helpful when dealing with solvents or other organic chemicals (including acids) that can have both an organic and $\mathrm{pH}$ effect on a given polymer. 
The Hildebrand solubility parameter $(\delta)$ was developed in 1936 by Dr. Joel Henry Hildebrand who suggested that the square root of the cohesive energy density as a numerical value indicated solvency behavior [27]. The term "solubility parameter" was not commonly used until much later (1950). The SI unit for the solubility parameter is $\mathrm{MPa} 1 / 2$.

Hildebrand solubility parameters have been used for many years by polymer chemists and paint formulators to predict material interactions. When dealing with polymers, the general concept of "like dissolves like" is usually a very good, common sense indication of whether or not a significant interaction will occur (dissolution, softening, swelling, etc.). As an example, silicone elastomers are resistant to many fluids and lubricants but are rapidly degraded in the presence of silicone oils or lubricants. Conversely, EPDM elastomer is readily attacked by certain hydrocarbon fluids and oils.

However, the Hildebrand solubility parameter has limited value when dealing with chemicals and materials that have significant polarity and/or hydrogen bonding effects. It is also of limited value when evaluating potential effects of solvent or chemical mixtures.

To overcome these limitations, two and three-component solubility parameters were later developed. Currently, the most widely used three-component solubility parameters are the Hansen Solubility Parameters (HSPs) developed by Charles M. Hansen in 1966 [27]. The HSPs divides the total Hildebrand value into three parts: a dispersion force component, a hydrogen bonding component, and a polar component. The Hansen parameters are additive such that the sum of each squared component is equal to the total Hildebrand parameter. Over the years, HSP values have been determined for many solvents, chemicals and polymers and can be found in several references $[27,28]$.

Hansen used a three-dimensional model to plot polymer solubilities. By doubling the dispersion parameter axis, an approximately spherical volume of solubility is formed for a given polymer. The radius of the sphere is called the interaction radius $(\mathrm{R})$. Therefore, a given polymer is likely soluble in a solvent (or organic chemical) if the Hansen parameters for the solvent lie within the solubility sphere for the polymer. For a given polymer, this determination requires a calculation of whether the distance of the solvent from the center of the polymer solubility sphere is less than the radius of interaction for the polymer.

Hansen solubility parameters for glycolic acid and formic acid are given in Table 3 [27, 28]. From a comparison of these values one can reasonably conclude that formic acid is likely to be more aggressive toward polymers with a significant contribution of hydrogen and/or polar bonding, such as polyamides (nylons). This type of analysis is consistent with empirical data that formic acid is a very effective solvent for nylons which are known to be resistant to many conventional solvents [31]. However, different values for the HSP can be found in different references, so conclusive statements solely from these values cannot be made. 
Table 3 Hansen Solubility Parameters for Formic and Glycolic Acids [27, 28]

\begin{tabular}{|l|c|c|c|}
\hline \multicolumn{1}{|c|}{ Acid } & Dispersion & Dipole & Hydrogen \\
\hline Formic acid & 14.6 & 10.0 & 22.1 \\
\hline Glycolic acid & 11.7 & 6.2 & 12.5 \\
\hline
\end{tabular}

For polymers that are currently exposed to formic acid and performing satisfactorily, glycolic acid is unlikely to pose a higher potential for degradation. However, further evaluation of HSPs for various polymers relative to formic acid and glycolic acid interactions is therefore recommended to identify any specific interactions that may be of concern.

The available data for the corrosion resistance or degradation resistance to glycolic acid is limited for the metallic and polymeric materials of construction. These data were generally from compatibility guides are often based on limited data. These guides are mostly suitable for general selection or relative rankings. Material variations such as form (plate, pipe, etc.) or polymer composition (different resins for polymers, additives, etc.) are often not considered. Most of the data applies directly to fairly pure glycolic acid, which shows good to excellent corrosion rates for the metallic materials of construction at low temperatures and good stability for most polymeric materials. These data would be applicable for the vessels and piping that store and transport the glycolic acid prior to addition to the sludge. However, at higher temperatures the data are more variable or inconsistent.

\subsection{Recommended Testing}

Based on the literature review, limited data are available that applies directly to the DWPF process vessels and other facilities downstream for both metallic and polymeric materials of construction. The finding during the glycolic acid flowsheet demonstration testing for the CPC that the glycolic acid based solutions reduced the residue build up from metal and glass indicates a possible corrosive nature or synergy between the glycolic acid and the DWPF sludge simulant.

Since corrosion is accelerated at elevated temperatures, testing for critical components which are at elevated temperatures is recommended such as the heating coils or hot surfaces (SRAT, SME and evaporator), condensers (for SRAT/SME and melter off gas, especially piping), and melter components (bubbler). From the literature review, the elevated temperature data showed limited usefulness for the austenitic stainless steels (less than $70{ }^{\circ} \mathrm{C}$ ) and for $\mathrm{C} 276$ showed variable data (2 versus 20 mpy for $93{ }^{\circ} \mathrm{C}$ ). Inconel (unspecified alloy) had unacceptable corrosion rates $(>50 \mathrm{mpy}$ ) at temperatures of $100{ }^{\circ} \mathrm{C}$.

The recommended testing consists of electrochemical testing and short-term hot-wall testing for $\mathrm{CPC}$ and off gas condensate vessels; melter coupon testing for the resistance of 690 to molten glass, melt-line and vapor space corrosion; and polymer exposure tests. The short-term hot wall test provides corrosion data for materials under heat transfer conditions. 


\subsection{Electrochemical Testing}

The electrochemical testing provides an accelerated means of evaluating the corrosion rate as well as the susceptibility to localized corrosion, i.e. pitting, stress corrosion cracking and possibly crevice corrosion. These tests would be expected to take approximately one-day per test condition. The electrochemical testing would be conducted to develop estimates of corrosion rates and susceptibility to localized corrosion for solutions of concern. This testing would be similar to that conducted previously for DWPF flowsheet changes $[18,19]$. These solutions would be SRAT/SME solutions representing sludge with the addition of glycolic acid and anticipated solutions for recycle and off-gas condensates. The representative SRAT solutions would be to evaluate the extremes for ferric concentrations at high concentrations for chloride, sulfate and mercury, which are known to have detrimental effects on corrosion and the antifoaming agent, which may be inhibitive. Testing at the range extremes or the anticipated minimum and maximum for the iron concentration was selected because of the beneficial effect iron showed on reducing corrosion in the presence of glycolic acid. Ambient and high temperatures are recommended for some solutions to understand the effect of temperature on the corrosion. Additionally, testing with formic acid additions should be performed to develop a baseline of comparison for the glycolic acid results. The materials of construction that would be tested include C276, Stellite 6B, Ultimet (CPC vessels and melter quencher), G30 (2H evaporator), and Allcorr (melter quencher). Since variable corrosion rates were reported for $316 \mathrm{~L}$ and $304 \mathrm{~L}$, testing of these alloys in $70 \%$ glycolic acid is recommended to assess the corrosion for storage vessels, transport piping, pumps and valves.

The electrochemical testing would consist of a series of tests including open-circuit potential monitoring (OCP), linear polarization resistance (LPR) and cyclic potentiodynamic polarization (CPP). The OCP follows changes in the sample potential which can be indicative of changes in the active corrosion mechanism. The LPR test, which provides a measure of the corrosion rate, will be performed in conjunction with the OCP testing. The LPR test requires a small perturbation of the potential from the steady state. The CPP tests provide a measure of the susceptibility to localized corrosion and require a significant polarization of the sample from the steady state. This series of test is anticipated to take one day for each condition (solution/temperature). In conjunction with this test, ASTM G5 will be conducted to check the instrumentation prior to and after this testing [20], as well as baseline experiments using formic acid as the reductant. These additional tests would take approximately a day/condition.

\subsection{Hot-wall Corrosion Testing}

Hot-wall corrosion tests are performed to determine corrosion rates for materials exposed to solutions under heat flux conditions. Similar testing was performed when an increased nitric acid concentration was planned for DWPF [18]. Several heated surfaces are of concern with the DWPF process and downstream including heating coils in the CPC vessels and the high level waste evaporator.

The hot-wall test involves heating one side of a metal disc specimen while the other side of the specimen is exposed to a corrosive test solution as shown in Figure 3. 
Temperature on the hot-wall side is measured by a thermocouple through the heating block and is set to the temperature of the heating coil or tube surfaces. A reflux condenser maintains liquid level, and a cold finger condenser is used to maintain the bulk of the solution below the boiling point. The test solution would be based on nominal chemistries for the recycle and off gas streams with the concentrations of glycolic acid, chlorides, sulfate and mercury at the high levels of expected ranges. Actual test solutions would be based on the results from the accelerated electrochemical tests. The test would operate for one month after which the samples would be analyzed for weight loss and examined microscopically to determine the corrosion morphology. If pitting or crevice corrosion occurred the depth of attack would be measured.

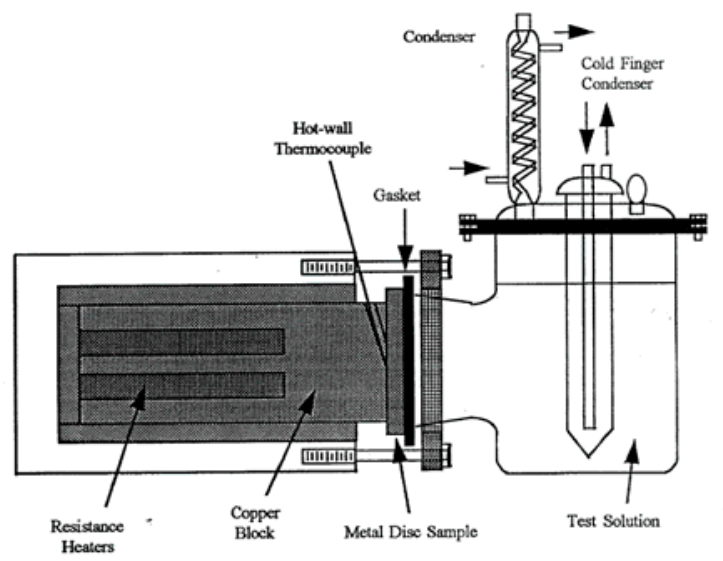

Figure 3 Hot-wall testing apparatus for testing corrosion resistance of materials under heat transfer conditions [18]

\subsection{Melter Coupon Test}

Glycolic acid will be carried over into the melter and its effect on Inconel 690 (I690) at elevated temperatures is unknown. As stated above, sulfate is an impurity in glycolic acid. Sulfates have been shown to cause significant damage to nickel-based alloys including I690 in melter applications [33, 34]. A coupon test is recommended during the off-gas flammability and cold cap behavior melter campaign. A new I690 bubbler, which will span the vapor, cold cap, melt line, and the molten glass regions, will be used as the test coupon. Following the melter exposure, the bubbler will be sectioned in each of the critical regions and metallurgically evaluated in accordance with ASTM G54 [21]. The evaluation includes an assessment of the thickness loss $\left(t_{o}-t_{f}\right)$, depth of internal attack $\left(\mathrm{d}_{\mathrm{ia}}\right)$, as well as characterization of internal voids and intergranular attack as shown in Figure 4. 

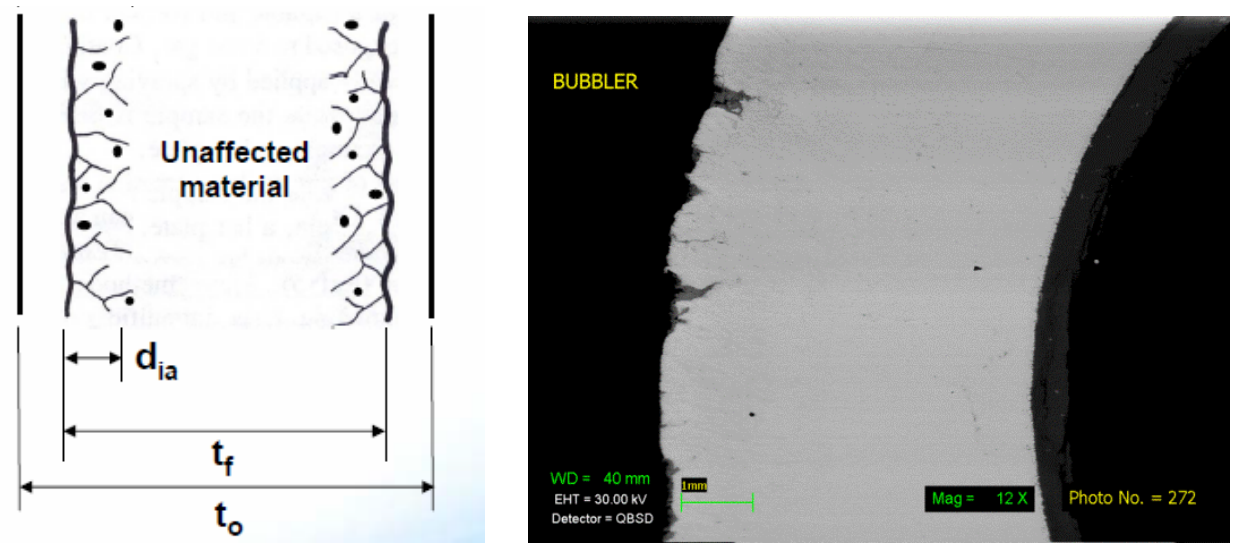

Figure 4 Melter coupon analysis per ASTM G54 [21]

These data can be compared with historical data of bubbler performance. Additionally, since the off-gas line would be a concern this line can be inspected for attack, such as pitting, after the melter test.

\subsection{Polymer Compatibility Testing}

Several polymers used in the applicable facilities would be evaluated using a dual approach. The Hansen solubility parameters for all relevant polymers relative to glycolic and formic acids would be evaluated for relative sensitivity. To validate such results, immersion testing of these polymers in representative solutions (including $70 \%$ glycolic acid in feed storage and process simulants) would be performed. Exposure to formic acid solutions would be performed for comparison. As a minimum, changes in polymer sample dimensions, weight, appearance, surface tackiness (evidence of chemical interaction) and hardness is recommended. Additional characterizations via FT-IR spectroscopy, optical microscopy and other techniques may also be needed depending on immersion results. The effect of glycolates and other byproducts of chemical interactions within the process or resulting from radiolytic breakdown of glycolic acid should also be considered. Solutions would be irradiated to evaluate potential effects of radiolytic breakdown byproducts. The information obtained would be used to determine the relative effects of glycolic acid on polymeric materials in DWPF and downstream facilities.

\subsection{Liquid Level Determination}

The liquid level of formic acid in DWPF storage tanks and other equipment has been periodically determined by non-destructive examination (NDE) using an ultrasonic (UT) time of flight measurement technique. Determining liquid levels in formic acid storage tanks has been known to be difficult, depending on tank size and relative surface activity. Accuracy of the existing, installed in-tank instrumentation for monitoring formic acid levels has been questionable and troublesome at times, requiring a second methodology for confirmation. SRNL has successfully used low frequency ultrasound capable of wave propagation in the formic acid for real time level measurement applied to the exteriors of the tanks. The ability of such wave propagation in a glycolic acid environment has not been previously documented and may or may not be possible. Therefore, some level of testing is recommended to evaluate the feasibility of using UT or other noninvasive NDE 
techniques to measure liquid level or other desirable attributes of glycolic acid in DWPF storage tanks and related equipment.

\subsection{Conclusions and Recommendations}

Glycolic acid is being evaluated as an alternative for formic and nitric acid in the DWPF flowsheet. Demonstration testing and modeling for this new flowsheet has shown that glycolic acid and glycolate has a potential to remain in certain streams generated during the production of the nuclear waste glass. A literature review was conducted to assess the impact of glycolic acid on the corrosion of the materials of construction for the DWPF facility as well as facilities downstream which may have residual glycolic acid and glycolates present. The literature data was limited to solutions containing principally glycolic acid. The reported corrosion rates and degradation characteristics have shown the following for the materials of construction.

- For C276 alloy, the primary material of construction for the CPC vessels, corrosion rates of either 2 or 20 mpy were reported up to a temperature of 93 C.

- For the austenitic stainless steels, 304L and 316L, variable rates were reported over a range of temperatures, varying from 2 mpy up to 200 mpy (at 100 C).

- For 690, G30, Allcorr, Ultimet and Stellite alloys no data were available.

- For relevant polymers where data are available, the data suggests that exposure to glycolic acid is not detrimental.

The literature data had limited application to the DWPF process since only the storage and feed vessels, pumps and piping used to handle the glycolic acid are directly covered by the available data. These components are either 304L or 316L alloys for which the literature data is inconsistent (See Bullet 2 above). Corrosion rates in pure glycolic acid solutions also are not representative of the DWPF process streams. This stream is complex and contains aggressive species, i.e. chlorides, sulfates, mercury, as well as antifoaming agents which cumulatively have an unknown effect on the corrosion rates of the materials of construction. Therefore, testing is recommended to investigate any synergistic effects of the aggressive species and to verify the performance of materials in the key process vessels as well as downstream vessels and processes such as the evaporator where heating is occurring. The following testing would provide data for establishing the viability of these components.

- Electrochemical testing - evaluate the corrosion rate and susceptibility to localized corrosion within the SRAT, SME, OGCT, Quencher and Evaporator. Testing would be conducted at operational temperatures in simulants with ranges of glycolic acid, iron, chloride and mercury and antifoaming agents.

- Hot-wall testing - evaluate the corrosion under heat transfer conditions to simulate those for heating coils and evaporator coil surfaces. Testing would be at nominal 
chemistries with concentration of glycolic acid, chloride, sulfate, and mercury at high expected concentrations. Some tests would be performed with antifoaming agents.

- Melter coupon testing - evaluate the performance of 690 in melter feeds which will contain glycolic acid in the feed. This testing would be conducted as part of the melter flammability testing.

- Polymer testing - analyze the Hansen solubility parameters for relevant polymers in glycolic vs. formic acid and evaluate changes in polymer properties in immersion testing with DWPF simulants to provide product-specific data for service life evaluation.

- Liquid level determination - evaluate the feasibility of using ultrasonic inspection techniques to determine liquid level and other desirable attributes of glycolic acid in DWPF storage tanks and related equipment.

\subsection{References}

1. Task Technical Request: Impact of Nitric-Glycolic Acid Flowsheet - Material Evaluation for DWPF and Downstream Tank Farm Processes, HLW-DWPF-TTR2013-0004, Revision 0, October 31, 2012

2. J. I. Mickalonis and K. J. Imrich, "Task Technical and Quality Assurance Plan for Material Evaulation for DWPF Nitric-Glycolic Acid Flowsheet," SRNL-RP-201200834, Revision 0, December 7, 2012

3. "Glycolic Acid Properties, Uses, Storage, and Handling", Dupont Specialty Chemicals

4. D.P. Lambert, M.E. Stone, J.D. Newell, D.R. Best, and J.R. Zamecnik, "GlycolicNitric Acid Flowsheet Demonstration of the DWPF Chemical Process Cell with Sludge and Supernate Simulants, SRNL-STI-2012-00018, Revision 1, August 2012

5. B. R. Pickenheim and N. E. Bibler, "Glycolic Acid Physical Properties, Impurities, and Radiation Effects Assessment, SRNL-STI-2010-00314, Revision 0, May 24, 2010

6. J. I. Mickalonis, "Corrosion Testing in Support of DWPF High Sulfate Feed," WSRC-TR-2003-00076, Revision 0, March 15, 2002

7. B. R. Pickenheim, M. E. Stone, and D. K. Peeler, "Selection and Preliminary Evaluation of Alternative Reductants for SRAT Processing," SRNL-STI-2009-00120, Revision 0, June, 2009

8. K. M. L. Taylor-Pashow, T. B. Peters, F. F. Fondeur, T. C. Shehee, and A. L. Washington, "Determination of the Impact of Glycolate on ARP and MCU Operations, SRNL-STI-2012-00218, Revision 1, December, 2012

9. K. Adu-Wusu, "Literature Review on Impact of Glycolate on the $2 \mathrm{H}$ Evaporator and the Effluent Treatment Facility (ETF), SRNL-STI-2012-00132, Revision 0, May 2012 
10. A. S. Choi, "Melter Off-Gas Flammability Assessment for DWPF Alternate Reductant Flowsheet Options, SRNL-STI-2012-00321, Revision 0, July 2011

11. W. L. Daugherty, "Evaluation of Potential for Materials Degradation of DWPF Safety Class and Safety Significant Components," WSRC-Tr-95-0385, Revision 0, September 1995

12. Cleaning and Descaling Stainless Steels, Designer Handbook Series No 9001, Nickel Development Institute, 1988

13. K. M. Pruett, Chemical Resistance Guide for Metals and Alloys, Compass Publications, La Mesa CA, 1995

14. Corrosion Data Survey, Metals Section, $6^{\text {th }}$ Ed., National Association of Corrosion Engineers, Houston TX, 1995

15. P. A. Schweitzer, Corrosion Resistance Tables, $3^{\text {rd }}$ Edition, Marcel Dekker Inc., New York NY, 1991

16. Chemical Resistance Guide, Burkertt Fluid Control Systems, Ingelfingen, Germany

17. Email communication, Mark C.P. Darey, Glycolic Acid Technical Consultant, Dupont Chemicals and Fluoroproducts

18. G. T. Chandler, P. E. Zapp, and J. I. Mickalonis, "Hot-Wall Corrosion Testing Of Simulated High-Level Nuclear Waste," CORROSION/95, Paper no. 431 (Houston, TX: NACE International), 1995

19. J. I. Mickalonis, "Corrosion Testing in Support of DWPF High Sulfate Feed," WSRC-TR-2003-00076, Revision 1, March 15, 2003

20. ASTM G54-84, Reapproved 1996, Standard Practice for Simple Oxidation Test, ASTM International, West Conshohcocken, PA, 2013

21. ASTM G5-13, Standard Reference Test for Making Potentiodynamic Anodic Polarization Measurements, ASTM International, West Conshohcocken, PA, 2013

22. D. P. Lambert, D. C. Koopman, J. D. Newell, D. T. Wasan, A. P. Nikolov, and E. K. Weinheimer, "Improved Antifoam Agen Study End of Year Report, EM Project 3.2.2," SRNL-STI-2011-00515, September 30, 2011

23. S. Meth, N. Savchenko, F. A. Viva, D. Starosvetsky, and A. Groysman, "Siloxanebased Thin Films for Corrosion Protection of Stainless Steel in Chloride Media," J Applied Electrochemistry, Vol 41, 2011, pp 885-890

24. L. Zhou, G-H Lv, C. Ji, and S-Z Yang, "Application of Plasma Polymerized Siloxane Films for the Corrosion Protection of Titanium Alloys," Thin Solid Films, Vol 520, 2012, pp 2505-2509

25. A. M. Beccaria and L. Chiaruttini, "The Inhibitive Action of Metacryloxypropylmethoxysilane (MAOS) on Aluminum Corrosion in $\mathrm{NaCl}$ Solutions," Corrosion Science, Vol 41, 1999, pp 885-890

26. V. D. Atkinson, Corrosion and Its Control, NACE International, Houston TX, 1995, pp 57-62 
27. C. M. Hansen, Hansen Solubility Parameters: A User Handbook, CRC Ppress, Boca Raton FL, 1983

28. A.F.M.Barton, Handbook of Solubility Parameters and Other Cohesion Parameters, 2nd d Ed., CRC Press, 1983

29. K. M. Pruett, Chemical Resistance Guide for Plastics, Compass Publications, La Mesa CA, 2000

30. K. M. Pruett, Chemical Resistance Guide for Elastomers III, Compass Publications, La Mesa CA, 2005

31. R. Puffr, V. Kubanek, Lactam-Based Polyamides: Volume I, Polymerization, Structure, and Properties, CRC Press, 1991

32. C. J. Martino, "Simulated Waste Testing of Glycolate Impacts on the 2H Evaporator System," SRNL-STE-2013-00166, in draft

33. K. J. Imrich, "DWPF Sludge Batch 3 Molten Glass/Vapor Space Corrosion Test Results," WSRC-TR-2004-00530, Revision 0, September 15, 2005

34. K. J. Imrich," Material Performance of DWPF Melter Top Head and Off Gas Components (U)," WSRC-TR-95-0234, August 16, 1996 


\section{APPENDIX I}

The compositions given in Table AI-1 are for the metallic materials of construction within DWPF process and downstream facilities impacted by the presence of glycolic acid or glycolates.

Table AI-1 Metallic materials of construction nominal compositions

\begin{tabular}{|l|c|c|c|c|c|c|c|c|c|}
\hline Material & $\mathbf{C}$ & $\mathbf{C r}$ & $\mathbf{N i}$ & $\mathbf{F e}$ & $\mathbf{M n}$ & $\mathbf{M o}$ & $\mathbf{S i}$ & $\mathbf{W}$ & $\mathbf{C o}$ \\
\hline $304 \mathrm{~L}$ & $<0.03$ & $18-20$. & $8-12$ & $\mathrm{Bal}$ & $<2.0$ & & $<0.75$ & & \\
\hline 316 & 0.08 & $16-18$ & $10-14$ & $\mathrm{Bal}$ & $<2.0$ & $2-3$ & $<0.75$ & & \\
\hline Stellite & $1.4-1.7$ & $27-32$ & & & & & & $7.5-9.5$ & $\mathrm{Bal}$ \\
\hline Ultimet & 0.06 & 26 & 9 & 3 & 0.8 & 5 & 0.3 & 2 & 54 \\
\hline C276 & & $14.5-16.5$ & 55 & $4-7$ & & $15-17$ & & $3-4.5$ & \\
\hline G30** & $<0.03$ & $28-31.5$ & 43 & $13-17$ & $<1.5$ & $4-6$ & $<0.8$ & $1.5-4$ & $<5$ \\
\hline 690 & $<0.05$ & $27-31$ & 58 & & $<0.5$ & & $<0.5$ & & \\
\hline Allcorr*** & $<0.15$ & $27-33$ & & & & $8-12$ & & $<4$ & $<12$ \\
\hline A53**** & $<0.3$ & $<0.4$ & $<0.4$ & Bal & 1.2 & $<0.15$ & & & \\
\hline
\end{tabular}

$* \mathrm{Cu} 1.5-2.5, \mathrm{Nb} 0.3$

** Cu 1-2.4, Cb+Ta 0.3-1.5

$* * * \mathrm{Al}<1.5, \mathrm{Ti}<1.5, \mathrm{Nb}<2$

$* * * * \mathrm{Cu}-<0.4, \mathrm{~V}-<0.08$ 


\section{APPENDIX II}

The table below was taken from Reference 11 that summarizes the evaluated components and the observed corrosion rates for the DWPF Structural Integrity Program.

Table AII-1 Summary of Components Evaluated for DWPF Structural Integrity Program

\begin{tabular}{|c|c|c|}
\hline Component & Material & Corrosion Rate \\
\hline Precipitate Reactor (PR) & $\mathrm{C}-276$ & 5 mpy steam coils; 1 mpy remainder \\
\hline Organic Evaporator (OE) & $\mathrm{C}-276$ & 5 mpy steam coils; 1 mpy remainder \\
\hline OE Condensate Tank (OECT) & $304 \mathrm{~L}$ & 2 mpy, potential for local attack \\
\hline OE Condenser/Decanter (OECD) & C-276 & $<1 \mathrm{mpy}$ \\
\hline PR Condenser/Decanter (PRCD) & $\mathrm{C}-276$ & $<1$ mpy \\
\hline PR Feed Tank (PRFT) & C-276 & not quantified, but $<1 \mathrm{mpy}$ is expected \\
\hline PR Bottoms Tank (PRBT) & C-276 & $1 \mathrm{mpy}$ \\
\hline Slurry Mix Evaporator (SME) & $\mathrm{C}-276$ & $1 \mathrm{mpy}$, potential for erosion \\
\hline SME Condensate Tank (SMECT) & $316 \mathrm{~L}$ & $1-5 \mathrm{mpy}$ \\
\hline Sludge Receipt \& Adjustment Tank (SRAT) & C-276 & $1 \mathrm{mpy}$ \\
\hline Recycle Collection Tank (RCT) & C-276 & $1 \mathrm{mpy}$ \\
\hline Melter Feed Tank (MFT) & $\mathrm{C}-276$ & 1 mpy, potential for erosion \\
\hline Off-Gas Condensate Tank (OGCT) & $\mathrm{C}-276$ & $1 \mathrm{mpy}$ \\
\hline Steam Atomized Scrubber (SAS) & C-276 & $\begin{array}{l}\text { Vapor region - rate TBD; potential for } \\
\text { local attack. Liquid region - } 1 \text { mpy }\end{array}$ \\
\hline Off-Gas Condenser & $\mathrm{C}-276$ & $1 \mathrm{mpy}$ \\
\hline High Efficiency Mist Eliminator (HEME) & C-276 & $1 \mathrm{mpy}$ \\
\hline HEPA Filter Assembly & $304 \mathrm{~L}$ & $1 \mathrm{mpy}$ \\
\hline Off-Gas Quencher (OGQ) & $\begin{array}{l}\text { Allcorr } \\
\text { (primary) } \\
\text { \& C-276 } \\
\text { (backup) }\end{array}$ & $\begin{array}{l}\text { Liquid region - } 1 \text { mpy, primary; } 4 \text { mpy } \\
\text { with potential for local attack, backup } \\
\text { Vapor region - rate TBD; potential for } \\
\text { local attack }\end{array}$ \\
\hline Interarea Transfer Lines - inner pipe & $304 \mathrm{~L}$ & $0.5 \mathrm{mil} / \mathrm{yr}$ \\
\hline Interarea Transfer Lines - outer pipe & c. steel & $\begin{array}{l}1 \mathrm{mil} / \mathrm{yr} \text {, with local attack in vapor } \\
\text { space, if inner pipe leaks }\end{array}$ \\
\hline $\begin{array}{l}\text { Late Wash Facility (LWF) Precipitate Tank } \\
\text { (I WWPT) }\end{array}$ & $304 \mathrm{~L}$ & $0.5 \mathrm{mil} / \mathrm{yr}$ \\
\hline LWF Hold Tank (LWHT) & $304 \mathrm{~L}$ & $0.5 \mathrm{mil} / \mathrm{yr}$ \\
\hline $\begin{array}{l}\text { Low Point Pump Pit (LPPP) Sludge Tank } \\
\text { (SPT) }\end{array}$ & $304 \mathrm{~L}$ & $0.5 \mathrm{mil} / \mathrm{yr}$ \\
\hline LPPP Precipitate Tank (PPT) & $304 \mathrm{~L}$ & $0.5 \mathrm{mil} / \mathrm{yr}$ \\
\hline $\begin{array}{l}\text { Organic Waste Storage Tank (OWST) Inner } \\
\text { Tank }\end{array}$ & $304 \mathrm{~L}$ & $<2 \mathrm{mil} / \mathrm{yr}$ \\
\hline OWST Outer Tank & c. steel & $\begin{array}{l}\text { ranging from approx. } 0 \text { to }<20 \mathrm{mil} / \mathrm{yr} \text {, } \\
\text { depending on leakage, etc. }\end{array}$ \\
\hline OECT / OWST Transfer Pipe & $304 \mathrm{~L}$ & $<2 \mathrm{mil} / \mathrm{yr}$ \\
\hline Formic Acid Storage Tanks \#1 and 2 & $316 \mathrm{~L}$ & $<1 \mathrm{mil} / \mathrm{yr}$ \\
\hline Organic Acid Drain Catch Tank & $316 \mathrm{~L}$ & $<1 \mathrm{mil} / \mathrm{yr}$ \\
\hline Formic Acid Dilution Tank & $304 \mathrm{~L}$ & $<2$ mil/yr with potential for local attack \\
\hline Dilute Formic Acid Feed Tank & $304 \mathrm{~L}$ & $<2$ mil/yr with potential for local attack \\
\hline Formic Acid Feed Tank and piping & $316 \mathrm{~L}$ & $<1 \mathrm{mil} / \mathrm{yr}$ \\
\hline $\begin{array}{l}\text { Organic Acid Neutralization Waste Tanks } \\
\# 1 \text { and } \# 2\end{array}$ & $316 \mathrm{~L}$ & $<1 \mathrm{mil} / \mathrm{yr}$ \\
\hline Nitric Acid Feed Tank and piping & $304 \mathrm{~L}$ & $<2 \mathrm{mil} / \mathrm{yr}$ \\
\hline
\end{tabular}

Table continued on next page 
APPENDIX II continued

Table 1. Summary of Components Evaluated (continued).

\begin{tabular}{|c|c|c|}
\hline Nitric Acid Waste Hold Tank & $304 \mathrm{~L}$ & $<2 \mathrm{mil} / \mathrm{yr}$ \\
\hline Acid Drain Catch Tank & $304 \mathrm{~L}$ & $<2 \mathrm{mil} / \mathrm{yr}$ \\
\hline Nitric Acid Dilution Tank & $304 \mathrm{~L}$ & $<2 \mathrm{mil} / \mathrm{yr}$ \\
\hline Nitric Acid Dilution Tank piping & $304 \mathrm{~L}$ & $<2 \mathrm{mil} / \mathrm{yr}$ \\
\hline Canned motor pumps for various tanks & $304 \mathrm{~L}$ & approx. $0 \mathrm{mil} / \mathrm{yr}$ \\
\hline $\begin{array}{l}\text { Diesel Fuel Oil Storage Tanks \#1 and \#2 } \\
\text { and underground pipe }\end{array}$ & c. steel & approx. $0 \mathrm{mil} / \mathrm{yr}$, unless water is present \\
\hline Diesel Fuel Oil Day Tanks \#1 and \#2 & c. steel & approx. $0 \mathrm{mil} / \mathrm{yr}$, unless water is present \\
\hline Diesel Fuel Oil System piping & c. steel & approx. $0 \mathrm{mil} / \mathrm{yr}$, unless water is present \\
\hline Diesel Gen. System piping (air \& lube oil) & c. steel & approx. $0 \mathrm{mil} / \mathrm{yr}$, unless water is present \\
\hline Diesel Generator System piping (water) & c. steel & approx. $0 \mathrm{mil} / \mathrm{yr}$ \\
\hline Purge System Piping and Jumpers: & \multirow{6}{*}{$\begin{array}{l}304 \mathrm{~L}, \\
\mathrm{C}-276, \\
\text { galv. c. } \\
\text { steel, } \\
\text { \& copper }\end{array}$} & approx. $0 \mathrm{mil} / \mathrm{yr}$ \\
\hline LWF Primary (P) \& Backup (BU) & & approx. $0 \mathrm{mil} / \mathrm{yr}$ \\
\hline CPC Safety Grade (SG), P \& BU & & approx. $0 \mathrm{mil} / \mathrm{yr}$ \\
\hline SPC SG, P \& BU & & approx. $0 \mathrm{mil} / \mathrm{yr}$ \\
\hline LPPP SG \& P; OWST SG \& P & & approx. $0 \mathrm{mil} / \mathrm{yr}$ \\
\hline PPT/SPT Chem. Feed (LPPP SG) & & approx. $0 \mathrm{mil} / \mathrm{yr}$ \\
\hline $\begin{array}{l}\text { Purge System Tanks: } \\
\text { CPC SG, LPPP SG, OWST SG, } \\
\text { SPC SG, LWF P \& BU, } \\
\text { 422-S Supply Tanks }\end{array}$ & $\begin{array}{l}9 \% \mathrm{Ni} \text { steel } \\
\text { inner tank, } \\
\text { carbon steel } \\
\text { outer tank, }\end{array}$ & approx. $0 \mathrm{mil} / \mathrm{yr}$ \\
\hline SPC P and CPC P Tank & c. steel & approx. $0 \mathrm{mil} / \mathrm{yr}$ \\
\hline Purge System Vaporizers & $\mathrm{Al}$ & approx. $0 \mathrm{mil} / \mathrm{yr}$ \\
\hline $\begin{array}{l}\text { Vitrification Building: } \\
\text { Bldg. Structure, } \\
\text { SPC/CPC Removable Wall, } \\
\text { Remote Process Cell Covers, } \\
\text { Melt Cell Crane Rails \& Superstructure } \\
\end{array}$ & $\begin{array}{l}\text { coated } \\
\text { c. steel }\end{array}$ & $\begin{array}{l}\text { approx. } 0 \mathrm{mil} / \mathrm{yr} \text { if coating intact, } \\
<2 \mathrm{mil} / \mathrm{yr} \text { otherwise }\end{array}$ \\
\hline $\begin{array}{l}\text { Glass Waste Storage Building (GWSB) } \\
\text { Canister Supports }\end{array}$ & $\begin{array}{l}\text { galv. c } \\
\text { steel }\end{array}$ & $\begin{array}{l}\text { approx. } 0 \mathrm{mil} / \mathrm{yr} \text { if coating intact, } \\
<2 \mathrm{mil} / \mathrm{yr} \text { otherwise }\end{array}$ \\
\hline LWF Crane Rails and Superstructure & c. steel & $\begin{array}{l}\text { approx. } 0 \mathrm{mil} / \mathrm{yr} \text { if coating intact, } \\
<2 \mathrm{mil} / \mathrm{yr} \text { otherwise }\end{array}$ \\
\hline $\begin{array}{l}\text { LPPP Process Cell Crane Rails and } \\
\text { Superstructure }\end{array}$ & c. steel & $\begin{array}{l}\text { approx. } 0 \mathrm{mil} / \mathrm{yr} \text { if coating intact, } \\
<2 \mathrm{mil} / \mathrm{yr} \text { otherwise }\end{array}$ \\
\hline Zone 1 Exhaust Tunnel & $\begin{array}{l}\text { coated } \\
\text { c. steel }\end{array}$ & $\begin{array}{l}\text { approx. } 0 \mathrm{mil} / \mathrm{yr} \text { if coating intact, } \\
<2 \mathrm{mil} / \mathrm{yr} \text { otherwise }\end{array}$ \\
\hline Fan House Crane Rails and Superstructure & c. steel & $\begin{array}{l}\text { approx. } 0 \mathrm{mil} / \mathrm{yr} \text { if coating intact, } \\
<2 \mathrm{mil} / \mathrm{yr} \text { otherwise }\end{array}$ \\
\hline 422-S Superstructures & $\begin{array}{l}\text { coated- } \\
\text { c. steel }\end{array}$ & $\begin{array}{l}\text { approx. } 0 \mathrm{mil} / \mathrm{yr} \text { if coating intact, } \\
<2 \mathrm{mil} / \mathrm{yr} \text { otherwise }\end{array}$ \\
\hline
\end{tabular}




\section{Distribution:}

S. L. Marra

E. N. Hoffman

B. J. Giddings

D. R. Click

F. M. Pennebaker

R. E. Eibling

D. H. Miller

M. E. Stone

K. E. Zeigler

T. M. Adams

L. R. Bickford

T. L. Fellinger

E. J. Freed

E. W. Holtzscheiter

A. Samadi-Desfouli

M. E. Smith
773-A

999-W

786-5A

999-W

773-42A

999-W

999-W

999-W

773-41A

773-41A

730-A

704-26S

704-S

704-15S

704-27S

704-30S 